\title{
Optimizing Livestock Productivity Through Increased Feed Production in West Manggarai
}

\author{
Nancy Foeh ${ }^{1 *}$, Annytha Detha ${ }^{2}$, Nemay Ndaong 3 , Frans Umbu Datta ${ }^{4}$, Grace Maranatha ${ }^{5}$
}

1,2,3,4,5 Nusa Cendana University, Kupang, Indonesia

\section{A R T I C L E I N F O}

Article history:

Received 10 December 2019

Received in revised form

01 January 2020

Accepted 30 January 2020

Available online 28

February 2020

Keywords:

Livestock productivity,

optimizing, Increased feed
A B S T R A C T

The Aims of this activity to optimize livestock productivity through the independence and adequacy of animal feed, enhancing the beauty of the area through the use of livestock waste which has a significant impact on increasing livestock farmers' income in Nggorang Desa, Komodo District, West Manggarai, NTT. An initial survey to determine the location of the training venue was conducted in October 2018 in Nggorang Village, Komodo District, West Manggarai. Activities to introduce grazing land will be carried out on August 22-25, 2019 which is located in the Meeting Hall of the Village office in Nggorang. Participants in the extension activity were attended by 20 people from the cattle group of Nggorang Village, Komodo District, West Manggarai Regency. The approach method offered in the form of education and training is accompanied by the creation of a pilot model and assistance as well as evaluation monitoring. Training activities about Bokashi feed and waste processing technology and the application of integrated grazing land significantly increase farmers' understanding and skills in processing feed and livestock waste available in the environment, as well as supporting the independence of breeders in order to be able to optimize farm productivity through the utilization of integrated grazing land.

Copyright (C) Universitas Pendidikan Ganesha. All rights reserved.

\footnotetext{
* Corresponding author.

E-mail addresses: detha.air@staf.undana.ac.id (Annytha Detha)
} 


\section{Introduction}

Nggorang Village is an ideal area for livestock development through feed processing and utilization of agricultural waste because it is supported by natural conditions and water sources. Aside from having various types of livestock, Nggorang Village also has feed that comes from forage from pasture, residual waste from rice straw, and grass around the agricultural area. The natural resources of Nggorang Village can be a source of income that increases the economy of the village community. But in reality there are still many potential resources that cannot be utilized. Therefore we need counseling activities that are able to increase farmers' knowledge about animal feed processing and waste treatment based on the availability of forages, rice straw, and livestock waste.

Education and training activities are carried out by providing a pilot model of rice straw processing techniques which is the largest agricultural waste as the main source of animal feed (Hidayat 2014; Bata 2008) so that it can potentially create an integrated grazing area which is a center for raising livestock that is beautiful through the use of livestock manure, livestock waste becomes organic fertilizer using natural probiotics (Djuarnani 2004). This activity is expected to optimize livestock productivity through the independence and adequacy of animal feed, enhancing the beauty of the area through the use of livestock waste which has a significant impact on increasing livestock farmers' income in Nggorang Desa, Komodo District, West Manggarai, NTT.

\section{Methods}

An initial survey to determine the location of the training venue was conducted in October 2018 in Nggorang Village, Komodo District, West Manggarai. Activities to introduce grazing land will be carried out on August 22-25, 2019 which is located in the Meeting Hall of the Village office in Nggorang. Participants in the extension activity were attended by 20 people from the cattle group of Nggorang Village, Komodo District, West Manggarai Regency.

The approach method offered in the form of education and training is accompanied by the creation of a pilot model and assistance as well as evaluation monitoring. Education and training are carried out in two types which aim to increase the knowledge / understanding of farmers in terms of livestock raising management. This training focuses on techniques for making feed originating from local resources and techniques for making amoniase, so it is hoped that farmers can apply this well to be able to meet the needs of feed and no longer raise livestock. The training also focused on techniques for processing livestock and agricultural waste into organic fertilizer, compost and biogas which can be a new source of income for farmers or ranchers. In this training and education natural fermentation materials will be introduced as downstream from the results of the Special Team Research that has been produced so that it can benefit farmers or breeders (Detha et al. 2019; Detha et al. 2018, Foeh et al. 2019).

\section{Result and Discussion}

Based on the planned implementation method approach, training and education activities will be held on August 23-25, 2019. The training and education material is directed at increasing the knowledge / understanding of farmers in terms of good livestock raising management through the provision of feed and the introduction of feed making technology from sources. local power (Amoniase) by utilizing rice straw as agricultural waste that is very abundant in the Village of Nggorang.

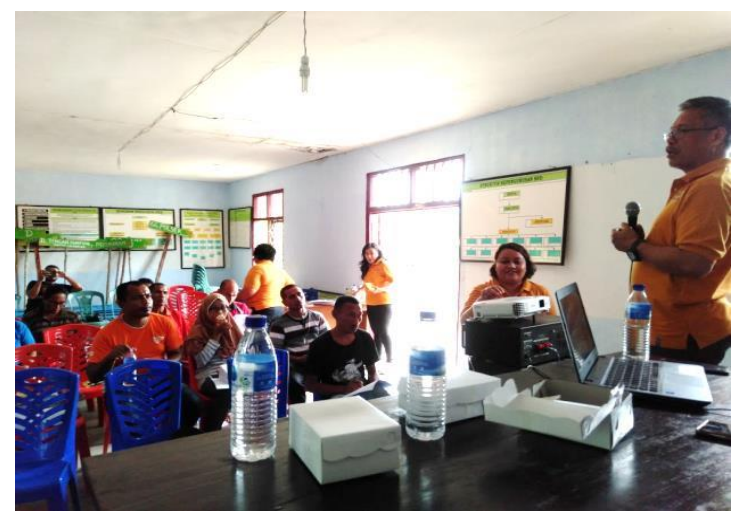

Figure 1. Training in animal feed processing technology and animal product waste 


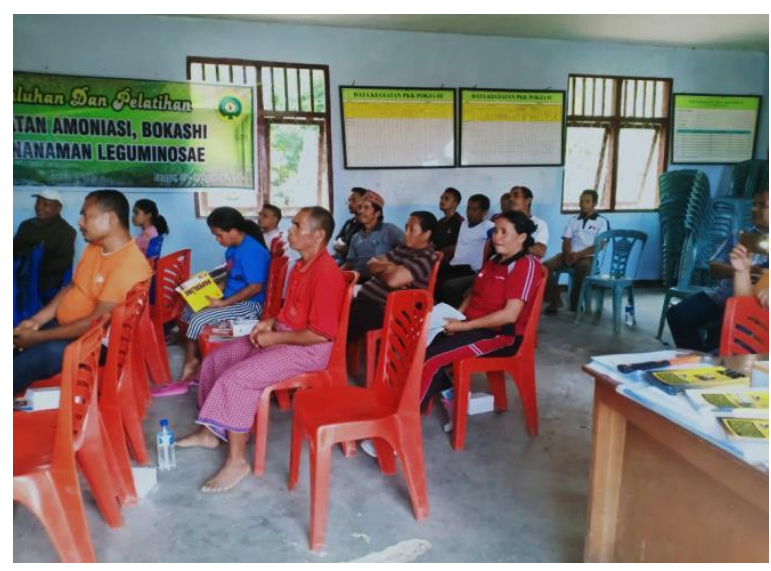

Figure 2. Participants in training

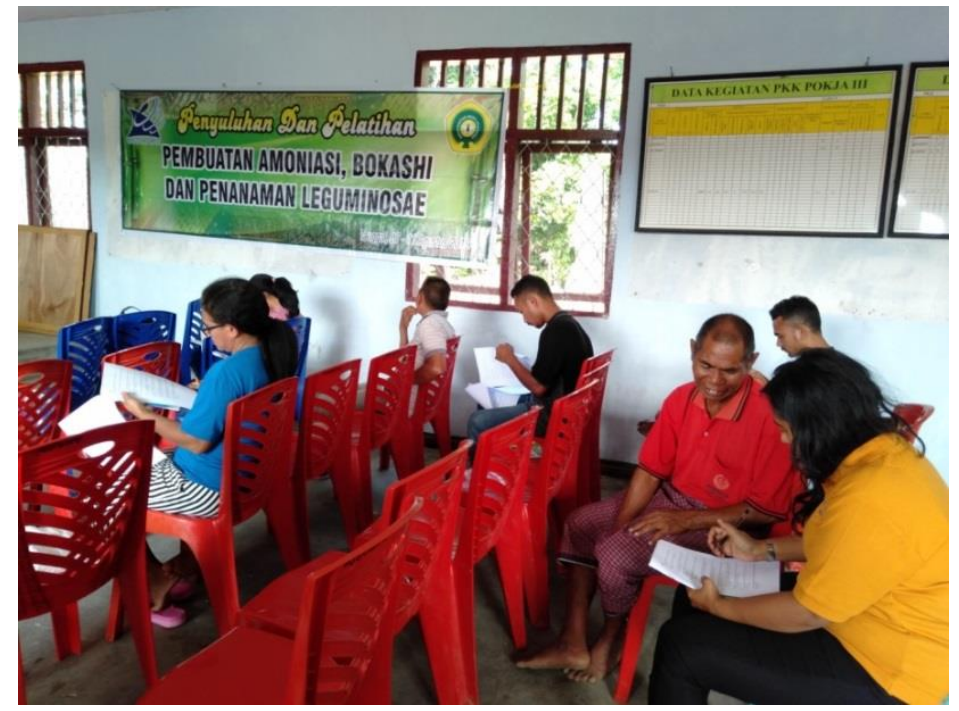

Figure 3. Participants fill out the Questionnaire after attending the Training

\section{Evaluation of Training}

The success measure of the training, at the end of the training an evaluation of the extent to which participants can absorb the material provided. Measuring instrument used for evaluation by distributing questionnaires containing questions about training activities and simulations that have been carried out.

\section{Application of Animal Feed Technology}

To measure the success of the training, at the end of the training an evaluation of the extent to which participants can absorb the material provided. Measuring instrument used for evaluation by distributing questionnaires containing questions about training activities and simulations that have been carried out. Based on the results of the questionnaire distributed, all participants answered that they could understand the material well and were able to implement it because the materials needed were very easy to obtain. In addition to training, the introduction of feed processing technology from rice straw in the form of simulations or demonstration plots was also carried out. The Amoniase manufacturing simulation was carried out in the front yard of the Nggorang village office. Participants actively participated in this training and actively participated in the process of making amoniase. In the simulation of making Amoniase from semi-dry or dry grass is carried out as follows: a number of 1000 grams of dry material, rice straw, $5 \%$ urea, $50 \%$ water and $30 \%$ molasses (Bata, 2008).

\section{Livestock Waste Management Technology}

Education and training are carried out to increase the knowledge / understanding of breeders in terms of good livestock maintenance management through the provision of feed and focus on techniques for making livestock and agricultural waste treatment into Bokashi. This education and training is supported by the brochure tool for making Bokahi so that it becomes a written media that can be read by 
farmers, especially the procedure for making Bokashi with its stages. Based on the results of filling out the questionnaire, all counseling participants understood very well the entire processing stage of Bokashi. This can be known by the results of the questionnaire answers given that know the ingredients needed in the manufacturing and work procedures for making Bokashi fertilizer.

\section{Application of Integrated Pasture Land}

Based on the results of the questionnaire, all participants answered that the advantage of implementing integrated grazing land was to be able to make labor efficient in supporting the availability of animal feed. All participants also promised that integrated grazing land would benefit integrated grazing to improve soil fertility and animal husbandry activities with an integrated grazing system to maintain the beauty of the surrounding environment. Some of the advantages of integrated grazing include integrated grazing as a combination of natural grasslands and natural forest ecosystems into open areas that can absorb surface water and from livestock manure released in integrated grazing can increase soil fertility; Integrated grazing that forms breeders' communities, information exchange media, animal transactions, and other social interactions; Breeding activities with an integrated grazing system to maintain the beauty of the surrounding environment; Use less labor; In addition, some cattles are used to work on agricultural land

\section{Conclusion}

Training activities about Bokashi feed and waste processing technology and the application of integrated grazing land significantly increase farmers' understanding and skills in processing feed and livestock waste available in the environment, as well as supporting the independence of breeders in order to be able to optimize farm productivity through the utilization of integrated grazing land.

\section{Reference}

Bata M. 2008. Pengaruh Molases Pada Amoniasi Jerami Padi Menggunakan Urea Terhadap Kecernaan Bahan Kering dan Bahan Organik In Vitro. Agripet Vol 8(2): 15-20.

Detha A, Datta FU, Beribe E, Foeh N, Ndaong N. 2018. Efektivitas Bakteri Asam Laktat yang Diisolasi dari Susu Kuda Sumba terhadap Kualitas Silase Jerami Padi. Jurnal Kajian Veteriner 6(1): 31-37.

Detha A, Ndaong N, Foeh N, Datta FU. 2019. Karakteristik Bakteri Asam Laktat Yang Diisolasi Dari Susu Kuda Sumba. Jurnal Kajian Veteriner 7(1): 85-92.

Djuarnani N, Setiawan BS. 2005. Cara Cepat Membuat Kompos. Jakarta: Agro Media.

Foeh N, Datta FUD, Detha A, Ndaong N. 2018. Isolation Of Lactic Acid Bacteria From Ruments Of Cattle As A Starter In The Manufacture Of Silage. Prosiding Seminar Internasional "5th ICAMBBE 2018, Swiss Belinn Hotel Malang, 3-4 September 2018".

Hidayat N. 2014. Karakteristik dan Kualitas Silase Rumput Raja Menggunakan Berbagai Sumber dan Tingkat Penambahan Karbohidrat. Agripet Vol 14 (1): 42-49.

Sutanto R. 2002. Pertanian organik: Menuju Pertanian Alternatif dan Berkelanjutan. Jakarta: Kanisius.. 